\title{
La feria discursiva de Juan José Arreola*
}

\author{
Ximena Troncoso Araos
}

Universidad de Concepción

\section{LA ESTRUCTURA DIALOGICA Y FRAGMENTARIA DE LA FERIA}

\begin{abstract}
A
Juan José Arreola se lo consideró un escritor desarraigado de la realidad mexicana en lo que a su obra se refiere, ya que en ella destacaban la fantasía, los espacios imaginarios, las temáticas universales y la intertextualidad erudita. Pero paulatinamente la crítica fue descubriendo las relaciones que sus cuentos establecen con el entorno sociocultural, ya como metáfora de un sistema deficiente, ya como parodia de discursos estereotipados [Menton 1963].

Su novela La feria (1963) es un texto esencialmente dialógico, pues, en palabras de Bakhtin [1989], "está lleno de ecos de otros enunciados". Dialoga con una diversidad de discursos sociales, lo que Bahktin llama la heteroglosia social [1985]. Dialoga con otros textos bíblicos (Isaías, Jeremías, Ezequiel), los Apócrifos y documentos históricos ${ }^{1}$. El texto establece una red de relaciones entre los fragmentos de que se compone, entre las voces y los discursos. Dialoga con la tradición literaria, de la que absorbe múltiples elementos como la parodia, la sátira, la ironía, la risa, el realismo, la fantasía, los digiere y crea una escritura y un texto singulares. Dialoga con el lector, del que requiere una participación muy activa en el proceso de construir la unidad textual. Dialoga con un tercero del discurso o un destinatario superior, al que me refiero en el último capítulo.
\end{abstract}

*El presente artículo constituye una primera parte de la tesis del mismo nombre defendida en 1997 en el programa de Magíster en Literaturas Hispánicas (Universidad de Concepción, profesor tutor Mario Rodríguez Fernández).

${ }^{1}$ Mauricio Ostria, en "Función de la intertextualidad en la obra de Juan José Arreola", reconoce las relaciones que la obra del autor, especialmente Confabulario, establece con otros textos literarios y con otro tipo de textos como "los relatos que las culturas construyen y que están, por decirlo así, disponibles para insertarse en diversas creaciones (es el caso de los mitos, las leyendas, las tradiciones, las creencias, pero también los decires, refranes y expresiones tradidas)" [Ostria 1994: 890]. 
La heteroglosia ingresa al texto sometida al proceso de urdimbre textual, adquiriendo sentidos al ficcionalizarse y disponerse bajo el punto de vista del autor. El diálogo con el contexto lingüístico social (distintas voces y discursos pertenecientes al presente y al pasado cotidianos e históricos de un pueblo), significa un diálogo con toda una cultura, porque cuando se recrea un discurso se cita una ideología o una forma de ver el mundo.

Los discursos imitan una forma de habla mexicana y los acontecimientos hacen referencia al pueblo natal del autor, Zapotlán, actualmente Ciudad Guzmán. El texto es una feria de discursos en donde se encuentran los niveles culto, popular, formal e informal con sus combinaciones y diferencias generacionales. Desde una perspectiva retórica también es posible distinguir diversos tipos de discurso: periodístico, religioso bíblico y doctrinal, legislativo, epistolar, autobiográfico, versificación popular, etc. [Ostria 1970]. La oralidad tiene una presencia importante: la mayoría de los discursos corresponde a conversaciones callejeras, informales, cotidianas. Al igual que en una feria, hacemos un recorrido, a lo largo del cual escuchamos voces y al ir avanzando nos resuenan las que van quedando atrás con mayores o menores ecos. Las relaciones dialógicas no sólo se establecen con lo que Coseriu (1962) llama "contexto extraverbal", sino al interior del texto. La feria se estructura en base a una serie de 288 fragmentos yuxtapuestos sin orden aparente, sin una sucesión coordinada de acontecimientos. Sin embargo, el fragmento y su yuxtaposición no implican ausencia de relación ni de unidad de sentido. Se transgrede la coherencia lineal, pero se crea una coherencia global, a nivel de la macroestructura [Dijk 1984: 147-229]. La cohesión de los fragmentos resulta de la recurrencia de los hablantes, de algunos tipos de discurso y de ciertos temas, así como también del diálogo entre unos y otros y de una progresión de las acciones ya sea a nivel individual o colectivo ${ }^{2}$; además existe un núcleo espaciotemporal con el que otros espacios y tiempos se relacionan. Algunos mecanismos de relación son: a) secuencias narrativas en las que aparecen los mismos personajes o el mismo emisor; b) réplicas a otros fragmentos (contrapunto); c) anáforas.

Con respecto a los personajes y emisores, hay una serie de ellos identificables, nominados o innominados, que aparecen, desaparecen y reaparecen a lo largo del texto. Los emisores innominados son reconocibles por las características de sus discursos, ya sea por la forma en que se expresan o por ciertos referentes que los relacionan con un oficio, una situación, una experiencia o un problema particular, como el zapatero que prueba en el oficio de agricultor, el niño que se confiesa ante el cura, el joven que escribe en su diario de vida, el miem-

${ }^{2}$ Para los conceptos de recurrencia, progresión, coherencia, características definitorias de un texto, ver Textos y discursos de Gerardo Alvarez. 
bro del Ateneo Zaputlateno. En ciertos fragmentos el mismo personaje es el narrador de su historia (el zapatero, el miembro del Ateneo, el joven del diario de vida); en otros el discurso se presenta en estilo directo introducido por un narrador básico o por un narrador personal. Muchas veces las voces irrumpen sin introducción previa de narrador alguno. En ocasiones el personaje es aludido o es tema de conversación en diálogos de otros personajes.

Algunos temas recurrentes y los más abarcadores son el tema de la tierra y el de la feria. Carmen Mora Valcárcel [1990] considera que todas las historias caben dentro de estos dos grandes temas. El leit motiv de la tierra tiene varias aristas: la tierra como terruño, como pueblo con el que se entablan lazos de identidad; la tierra como espacio geográfico afectado por los temblores, que además afectan la fisonomía humana, sus formas sociales; la tierra cultivable, dadora de frutos, así como también negadora de éstos por los caprichos de la naturaleza; y el aspecto principal, las tierras de los indígenas, quienes entablan un litigio para recuperar lo que los españoles les arrebataron, litigio que se arrastra hasta nuestros tiempos. Este problema afecta a todo el pueblo, pero sin que se vean todos involucrados directamente, porque no todos son dueños de tierras ni todos son indígenas.

El tema de la feria es el que concierne a toda la gente del pueblo: se habla sobre ella, ya ensalzándola, ya criticándola; se hacen preparativos y se participa. Este es el acontecimiento más importante de Zapotlán y por el cual el pueblo es conocido en otras partes. La feria funciona como un fenómeno que configura y da identidad al pueblo, es decir, es resultado de una particular forma de vida social (que incluye las ideas), pero al mismo tiempo actúa como realimentación por la que los zapotlenses se reconocen de distintos modos. El tema de la feria es abarcador no sólo porque involucra a la mayoría, sino porque abarca diversos aspectos de la vida como el religioso y el recreativo desde distintas perspectivas, que son las de las diversas voces que circulan por el texto.

Dependiendo de las líneas de relación que se establezcan, es posible reconocer otros temas, unos más generales y abarcadores, otros más particulares, de modo que unos caben dentro de otros, dependiendo de lo abarcante o acotado del contexto que se elija. Algunos de esos temas son el amor, el poder económico, el honor, la prostitución, el sexo, la intelectualidad y la literatura, la religiosidad, etc.

La progresión funciona en fragmentos que a lo largo de la novela conforman una secuencia narrativa que en algunos casos va desde una situación inicial con un proyecto hasta un final que es el éxito o fracaso del mismo. Este es el caso de los apuntes del zapatero en los que relata en primera persona lo que ha hecho y lo que pretende hacer para llevar a feliz término la siembra, la que 
le garantizará el logro de su proyecto mayor que es ser agricultor; el tiempo de la narración es lineal y cada fragmento aporta nueva información. En el caso de la confesión del niño lo que varía es lo confesado, no la situación; la mayoría de los pecados tiene relación con el despertar sexual. También es visualizable una progresión en las acciones relacionadas con el problema de las tierras y la feria. El tema de la tierra avanza en tanto los indígenas realizan algunas acciones para recuperar sus terrenos, mientras otros hacen todo lo posible por impedirlo; sin embargo, no hay progresión en cuanto a la situación de los indígenas, pues el conflicto no se resuelve, queda en la demanda, en el grito, en el llanto, en la voz. También la feria como acontecimiento social avanza fragmentariamente desde la preparación, pasando por la realización, hasta momentos posteriores a ella correspondientes a los comentarios al respecto (transcurre un año).

Dentro de las historias privadas es reconocible un núcleo que se construye por la interrelación de varios personajes y que también avanza intermitentemente. Estas historias las constituyen don Fidencio, Chayo (hija de él), Odilón, don Abigaíl (tío del anterior), el licenciado padre de Odilón (ya fallecido), don Salva (el tendero, jefe y pretendiente de Chayo) y doña María la matraca en forma más indirecta. Cada personaje tiene su mundo privado y su propio discurso, los que establecen líneas de relación entre sí. Pero es la historia de Chayo y Odilón la que involucra de un modo u otro la historia de todos ellos. Tanto el idilio entre estos dos personajes como la muerte del licenciado dan tema de conversación a la gente del pueblo, ya sea a personajes ocasionales o voces anónimas.

Las relaciones se establecen entre fragmentos vecinos o distantes. Algunas historias o discursos se concentran en ciertas zonas del texto (la historia de Alejandrina, la zona de tolerancia), otras se extienden en forma irregular y fragmentaria a lo largo de la novela. Algunos fragmentos son réplicas a otros para entregar una visión diferente de un mismo tema o bien retoman la idea de un fragmento anterior incorporando nuevos elementos o bien al final del fragmento se dejan planteados los posibles hechos que vendrían y se retoman en un fragmento posterior.

La anáfora es otro mecanismo de relación: una palabra o frase dicha al final de un fragmento sirve a otro como elemento introductorio para abordar el mismo tema u otro. La anáfora funciona como elemento que permite hacer una réplica: "Es signo de fecundidad su abundancia" / "Abundancia, ¡madre! Somos un pueblo de muertos de hambre" (13); enganchar otro tema: "Y otra vez volvieron los cantos y el agua bendita" / "Bendita lluvia la que está cayendo" (52); acercar de modo contrastante: "Mañana mismo le voy a pedir que se case conmigo..." (Don Salva) / "Mañana mismo le voy a avisar a don Salva que 
ya no vas a trabajar con él" (Padre de Chayo) (173-174)3. Este procedimiento otorga a la estructura de la obra la idea de simultaneidad de aconteceres. Y reforzando la fragmentariedad, pero a la vez estableciendo una relación con otros discursos, con otra voz o con el propio discurso, algunos fragmentos comienzan de forma tal que hacen suponer que otras palabras lo preceden, esto es, el fragmento comienza cuando el discurso o el diálogo ya se ha iniciado: "Pues que hagan otra rifa, a ver quién se la saca" (59), "Bueno, ya basta; palo dado ni Dios lo quita" (77). El procedimiento le otorga al texto mayor vivacidad, es el intento de textualizar los actos de habla en el acontecer de los discursos. Lo complejo radica en darle movimiento a la colectividad y mostrarla como un bullir de voces, de modo tal que incluso sugiere el ejercicio de imaginarnos a los personajes y escucharlos a un mismo tiempo en los distintos lugares y situaciones.

Si se analiza La feria considerando la coherencia lineal, el texto transgrede la estructura textual. Los fragmentos vecinos muchas veces no tienen relación entre sí (en ese contexto inmediato, pero sí la tienen en el contexto mayor de la obra). Se cambia de emisor o personaje, de tema y tiempo de la enunciación, con lo que se quiebra la recurrencia. También se produce un quiebre entre los fragmentos que van urdiendo una historia y aquellas voces aisladas del anonimato de la calle o los ecos del pasado histórico.

La fragmentación de La feria es distinta a la usada en otros textos hispanoamericanos, en donde los espacios en blanco y las historias paralelas mantienen una clara secuencia narrativa. En la novela de Arreola el procedimiento es más radical por el gran número de fragmentos, voces, temas y situaciones, sumado a ello la ausencia de un narrador que los relacione. El texto produce la impresión de un paseo por casas, calles y plazas del pueblo y por distintos tiempos de su historia.

No obstante la minoritaria presencia de un narrador, éste tiene importancia al contextualizar el discurso cuando se cree necesario hacerlo. La información es la mínima para el sentido del fragmento y depende de cada caso. El narrador es importante también porque otorga variados tonos y perspectivas que van imprimiendo sentidos al entrar en relación con el discurso de los personajes: unas veces grave, otras festivo, otras más bien neutro. La ironía caracteriza algunas veces el discurso del narrador o bien éste completa el sentido irónico del fragmento al funcionar complementariamente con el discurso de los personajes. La función del narrador no es, por lo tanto, relacionar narrativamente los fragmentos. Cada uno de ellos puede ser considerado y analizado en forma sintagmática y paradigmática, es decir, cada uno como un todo

${ }^{3}$ Todas las citas de La feria corresponden a la edición de 1963, México, Joaquín Mortiz. 
caracterizable y a la vez puesto en funcionamiento dentro del texto, donde adquieren su sentido.

El dialogismo de La feria supone, como ya lo ha advertido la crítica, un lector muy activo. El lector ha de rastrear la continuidad dentro de la discontinuidad, armar discursos e historias; relacionar los fragmentos, las voces y los discursos y reconstruir así la unidad de la novela; reconocer los intertextos, tanto los tipos de discurso sociales como las citas de otros textos, porque el sentido del original se modifica al entrar en relación con el nuevo contexto.

\section{LA VOZ INDIGENA}

El discurso de los indígenas se diferencia de todos los demás tipos de discurso correspondientes a grupos humanos que el texto ficcionaliza en que es un discurso serio, muchas veces solemne, ajeno al tono paródico y a la risa. Esta diferencia otorga a los indígenas, como dice Poot-Herrera [1992], "un lugar prioritario en el texto, como si éste quisiera compensar el lugar que ocupan en la historia" (158). La voz de Juan Tepano manifiesta la identidad indígena en oposición a las "gentes de razón". En su discurso conviven elementos pertenecientes al imaginario indígena y al cristiano-católico. El fervor religioso se manifiesta en hechos como la participación activa en la festividad en honor al patrono San José, para la que se ofrecen como mayordomos, esto es, toman a su cargo la preparación de la fiesta. El fragmento más elocuente de la cosmovisión indígena y de su sincretismo con la religión católica es un hermoso pasaje en el que Juan Tepano rescata una historia que es vivida como verdad en el momento en que la enuncia:

-A los cuervos no les tires, Layo. Nomás espántalos, porque son cristianos igual que nosotros y no les hacen daño a la milpas. Ustedes ya no se acuerdan, pero los cuervos trajeron otra vez el maíz a Zapotlán, cuando nos lo quitaron las gentes de Sayula () Pero tuvimos un rey y su nahual era cuervo ( ) Y con los poderes antiguos de Topiltzin y Ometecutli, nos enseñó a todos para que nos volviéramos cuervos ( ) Y cuando comenzaron las lluvias, ya para meterse el sol, nos hacíamos cuervos y nos íbamos volando para buscar el maíz ( ) Pero como nos costaba mucho trabajo encontrar las semillas y todos teníamos ganas de comer maíz, nuestro Rey Cuervo dijo que quienes se tragaran el grano por el camino se quedarían ya de cuervos, volando y graznando entre los surcos, buscando para siempre el maíz enterrado. Y muchos de nosotros no se aguantaron las ganas y se tragaron el grano en vez de sembrarlo en nuestra tierra. Y ya no volvieron a ser hombres como nosotros...

La relación del indígena con su entorno es armónica e interdependiente. 
Los indígenas leen y se leen en la naturaleza: los indígenas de Zapotlán son cuervos, los cuervos son indígenas; los cuervos buscan el maíz al igual que los indígenas; por lo tanto, los cuervos no se matan, sólo se espantan. Tepano vive y revive la tradición oral en el relato fabuloso. Esta es una de las formas como dialoga con las voces de sus antepasados y a la vez con las de sus congéneres, por ser la voz autorizada que recoge y transmite la cultura.

El diálogo de la voz indígena también establece lazos con la cultura europea cristiana, específicamente la española católica, fundamentalmente en la religión: el culto a Dios, la virgen y los santos que ellos integran a su cultura. La cosmovisión cristiano-católica no viene a reemplazar a la indígena ni logra transformarla por completo. El discurso indígena trasciende el orden cristiano eclesiástico, el discurso oficial, y se refugia en otro, un orden divino más integrador y más concreto, porque la marcha del mundo responde a un orden universal con leyes naturales superiores. Los indígenas viven una relación simbiótica con su entorno, cualquier cambio en la naturaleza redunda de una otra forma en los elementos que la componen. De ahí la cautela para relacionarse con ella, para intervenir en el curso de los fenómenos físicos. Esta visión hace al discurso indígena más religioso y más solemne. Los personajes no indígenas viven la religión como fuente de beneficios o tabla de salvación: fe en alguien superior que da bienes y evita males. Los indígenas, por su panteísmo y animismo, extienden la dimensión religiosa del individuo al mundo natural, con el que experimentan un diálogo constante.

En el fragmento que abre la novela nuevamente se abrazan el presente y el pasado en las palabras de la conciencia interior de Tepano, las que se traducen en una breve diacronía histórica de discursos que tienen en común el reclamo de un bien ante una autoridad, situación recurrente en la historia: "Señor Oidor, Señor Gobernador del Estado, Señor Obispo, Señor Capitán General, Señor Virrey de la Nueva España, Señor Presidente de la República ... Soy Juan Tepano, el más viejo de los tlayacanques, para servir a usted: nos lo quitaron todo..." (8). Lo memorable de estas palabras radica en la condensación de una historia de siglos: cambian las autoridades, pero la situación de los indígenas no varía. El escueto reclamo de Tepano es elocuente: "nos lo quitaron todo".

Los dueños de tierra emiten opiniones encontradas: para unos los indígenas son flojos y borrachos, motivo por el cual estarían donde están; otras voces adoptan una actitud más empática, considerando ciertas conductas como respuesta o consecuencia a las circunstancias históricas y sociales. De igual forma ocurre con el tema de la tierra: algunos consideran que la tierra es de los indígenas por derecho propio; otros, defendiendo sus posesiones, opinan que ya no les corresponde. Don Abigaíl sustenta la voz con mayor poder social, porque tiene el poder económico. Su discurso es claramente antiindígena y sus 
acciones también, pues solicita a la Iglesia que cambien al párroco, envía falsos anónimos y compra a un par de indígenas para que se responsabilicen de los hechos. El caso del licenciado no es muy distinto, ya que, si bien antes de morir confesó al sacerdote que iba a dejar su herencia a los indígenas, este gesto de generosidad no es tal, ya que lo motiva el deseo de no favorecer a su hermano. La imagen que los personajes tienen del licenciado es la de un avaro; no obstante, algunos muestran actitudes benevolentes, pero movidos por la tradicional misericordia para con los muertos: "-No hable usted mal de los muertos, al fin y al cabo ya no están en este mundo y no pueden hacernos nada" (49).

La Iglesia Católica posee una doble faz: la institución poderosa y celosa de su poder y la iglesia austera, desinteresada por lo material e interesada por los pobres de bienes materiales y por los pobres de espíritu. La Iglesia Católica como institución comulga con los intereses de los ricos y con sus propios intereses materiales. Los lugareños se percatan de esto, como el hombre que se niega a echar dinero en la alcancía de la iglesia para la construcción de un seminario: "Que la llenen los ricos, al cabo que son los que mejor se llevan con el cuerpo vivo de la Iglesia" (73). En el texto se evita la repetición de estos casos mediante la referencia que hace don Abigaíl en la carta al Reverendo Padre Superior: "Se ha observado un manifiesto sabotaje por lo que se refiere a las alcancías a beneficio del seminario. Nadie, entre las clases media y baja, parece dispuesto a echar en ellas un solo centavo" (150-151). La ayuda que los indígenas reciben de los religiosos procede de personajes aislados. En el texto el cura del pueblo tiene una actitud paternalista hacia los indígenas y los aconseja en relación a la defensa de sus tierras. Su postura resulta polémica y peligrosa, por lo tanto es destituido de su cargo. Por otra parte, según una voz, fue por culpa de la religión que perdieron sus tierras. Para argumentar sus opiniones basa su discurso en hechos históricos y envía a su interlocutor a fuentes directas:

Y a la hora que se vino la Reforma, en vez de que las capillas fueran de las tierras, resultó que las tierras eran de las capillas, y por lo tanto, del clero. Fueron puestas en venta, y ya sabe usted quiénes las compraron. Vaya, si no, a buscar los nombres en los archivos. Desde entonces data el verdadero pleito. Y como los indios tenían después de todo razón, al estar dale y dale, se ordenó el famoso reparto de 1902, que fue el fraude más grande y vergonzoso que registra la historia de este pueblo (35).

No obstante, hay una voz que se opone a esta argumentación diciendo que "no es cierto que nadie les haya quitado nada. Ellos lo han perdido todo por güevones, borrachos, gastadores y fiesteros" (35), el texto privilegia la primera postura al incorporar documentos históricos que la refuerzan. 
Uno de estos intertextos favorecedores de los indígenas corresponde a un escrito del mismísimo rey. Resulta irónico que, investido de toda su autoridad, ordene algo que no se hace: "Que sean tratados como lo merecen vasallos que tanto sirven a la monarquía y la han engrandecido y lustrado" (197). La voz del rey aparece en otros fragmentos más breves exhortando al buen trato para con los indígenas o reprendiendo el mal trato. Paradojalmente, la benevolencia del discurso del rey contrasta con la rapacería de las autoridades menores que tienen contacto directo con ellos. Juan Tepano está muy consciente de esta paradoja, la que cifra en una expresión popular: "Las autoridades de arriba nos dan la razón y las de abajo nos la quitan, ya ven ustedes, siempre han sido más bravos los tenajales que la cal" (28).

En varias ocasiones a lo largo del texto se incorporan citas bíblicas que apuntan al problema de la tierra, a la injusticia y a la ambición, la mayoría de las veces sin indicar que se trata de una cita. En el fragmento de la confesión se intercalan citas bíblicas, de las cuales la siguiente remite al problema de la tierra: "AAy de los que juntan casa con casa y campo con campo hasta ocuparlo todo!” (90), (Isaías 5: 8). Don Isaías, protestante, cada vez que tiene la palabra profiere un breve sermón incorporando a su discurso pasajes bíblicos. Este personaje se identifica con los pobres: "Habéis devorado la cosecha, y del despojo de los pobres están llenas vuestras casas" (63), (Isaías 3:14). En otro momento aparece un pasaje de Zacarías al que se le quita la referencia a Jerusalén y se lo vuelve más coloquial y actual en su lenguaje; además, se le antepone un guión para adjudicárselo a un emisor anónimo: “-Alcé los ojos y vi un hombre que tenía en la mano un cordel de medir y le pregunté qué andaba haciendo. Me dijo: Voy a medir la tierra para ver cuánta es su anchura y cuánta su longitud" (145), (Zac. 2: 1-2). La situación se especifica en los fragmentos que le siguen: los indígenas son quienes andan midiendo las tierras valiéndose de los mojones antiguos para argumentar sus derechos sobre ellas. Así, el texto utiliza la misma autoridad moral occidental para reivindicar las voces y acciones indígenas en su verdad, en su dolor y en su derecho.

\section{EL CARNAVAL RELIGIOSO}

La feria es la fiesta en honor al Santo Patrono San José. La fiesta religiosa pagana reúne algunas características del carnaval descrito por Bakhtin: "Una forma de espectáculo sincrético con carácter ritual. Se trata de una forma sumamente compleja, heterogénea, que siendo carnavalesca en su fundamento, tiene muchas variantes de acuerdo con las épocas, pueblos y festejos determinados" [1981: 172]. El carnaval es un espectáculo, pero sin el escenario que compren- 
de actores y espectadores, porque no se representa ni contempla, se vive [Bakhtin 1971: 13, 14]. El carnaval es la vida al revés, favorece el contacto libre y familiar entre la gente, rompe con las relaciones jerárquicas de poder y permite la manifestación de lo inconsciente. Pero la feria, a diferencia del carnaval de tradición medieval, es religiosa y tiene carácter mágico y encantatorio, pues piden beneficios a la vez que los agradecen.

La fiesta, y en especial la religiosa, adquiere características singulares en América, en donde la religión se vive materialmente: se honra y se celebra con todos los sentidos. En relación con esto, El laberinto de la soledad de Octavio Paz es iluminador. En estas fiestas, dice Paz, "se mezcla el bien con el mal, el día con la noche, lo santo con lo maldito" [1990: 46]: en la feria de Zapotlán se conjugan la devoción religiosa y las diversiones en un ambiente efervescente que favorece las más variadas manifestaciones y excesos. Es un evento social que congrega a todo el pueblo sin excepción: todos, indígenas y blancos, ricos y pobres, niños y adultos, participan y vibran con la espera y la realización del evento. La fiesta constituye un derroche, un gasto económico y energético excepcional: los días de feria son días de abundancia y dilapidación de comida, bebida, fuegos artificiales, juegos de feria, trajes, ofrendas. Este despilfarro, según Paz, "es una prueba de salud, una exhibición de abundancia y poder o una trampa mágica. Porque con el derroche se espera atraer, por contagio, a la verdadera abundancia" (44). La fiesta le brinda al pueblo y a cada habitante la posibilidad de salir de su silencio, de abrirse, de gritar, de bailar. La efervescencia del ambiente y de los ánimos provoca la expresión no sólo de alegría y devoción, sino también de dolor y odio. La gente no sólo reza y danza, también se emborracha y se mata. Para Octavio Paz, el desborde que significa la fiesta mexicana deriva de la común inhibición de sus habitantes, quienes liberan en esos momentos no sólo su sentir positivo y benéfico, sino también sus complejos, temores y frustraciones.

En La feria, la fiesta tiene mucho de libre expresión popular, aunque no deja de ser una fiesta oficial supervigilada por la iglesia y reglamentada por el municipio, los que tienen sus diferencias: "Por un lado está bien, pero por otro está mal. La Iglesia prohíbe las corridas de toros en los días del Novenario, pero el municipio las permite" (182). Por este motivo, si bien en el texto la fiesta trae consigo un desorden en relación al orden social habitual (la "gente del pueblo" sobre todo tiende a no respetar las diferencias de clase) y se hace más difícil hacer cumplir normas morales y sociales, se mantiene o confirma una estructura social que dice relación, principalmente, con el lugar que ocupan los indígenas, el cual pudiera parecer distinto al habitual por tener ellos el "honor" de cargar con el santo, pero es el mismo de siempre, el más bajo de la jerarquía. Un narrador en primera persona que se dirige a un destinatario plu- 
ral describe la escena, coincidiendo el presente del enunciado y el de la enunciación. Parece apelar al pueblo con el propósito de que abra los ojos a cierta realidad:

Ahora asómense para abajo. ¿¿ué es lo que ven? Sí, son ellos, los miembros de la Comunidad Indígena, que han alcanzado el honor de cargar con el santo y su gloria. Son cien o doscientos aplastados bajo el peso de tantas galas, cien o doscientos agachados que pujan por debajo, atenuando con la cobija sobre el hombro los filos de la madera, y que circulan en la sombra sus botellas de tequila para darse ánimos y fuerzas. En cada esquina el anda se detiene, y muchos se echan en el suelo, a descansar sobre las piedras...

¡Adelante con la superestructura, pueblo de Zapotlán! ¡Animo, cansados cireneos, que el anda se bambolea peligrosamente como una barcaza en el mar agitado de la borrachera y el descontento! (195).

La escena del paso de las andas envía metafóricamente a la situación indígena. Aplastados por la "superestructura", cargan, como Simón de Cirene, con una cruz que no les pertenece. El sistema social avanza, pero tambaleante, pues en sus bases se agita el descontento de los indígenas, quienes ocupan un lugar casi invisible y doloroso, en donde se infunden fuerzas con el alcohol.

La feria, como advierte Poot-Herrera, no es el carnaval que borra las fronteras sociales y económicas. Permite ciertas libertades, pero reproduce una estructura social estratificada en donde hay voces cuyos discursos se emiten desde el poder y se atribuyen el poder del dinero o de la moral. Por momentos se produce en Zapotlán un quiebre de las fronteras sociales, actos que nacen de las clases sociales bajas, pero que no son compartidos por las clases altas: algunos condenan el desorden como "intolerable y mal entendida democracia" y rescatan el supuesto orden que tuvo en otro tiempo: "Por el paseo de adentro circulaban las personas decentes; por el de afuera, los de sombrero ancho y de rebozo" (188). De igual forma rechazan las manifestaciones verbales populares de que son blanco y que "nacen al amparo de la algarabía y de las aglomeraciones" (187), como es el caso de las cancioncillas populares que ofenden a quienes las escuchan.

Algunas voces adoptan una actitud crítica para con la feria o mejor dicho para con el lucimiento personal de parte de la clase alta. Otras voces critican la feria comparándola con la de tiempos pasados, una supuesta edad de oro del pueblo de Zapotlán en que todo era más auténtico. Varias voces destacan la diferencia de la actual feria con las anteriores, cambios que apuntan a una restricción de la expresión y participación popular. También hay voces que rescatan lo positivo de la feria desde un punto de vista personal: "-Digan lo que quieran, a mí me encanta la chirimía” (173); "A mí lo que más me gustó 
fue ver otra vez los Paistes, que según creo es la danza más antigua” (180); “-La vela de doscientos pesos fue uno de los mejores éxitos de la feria”; “-Lo más hermoso fue el final de la ceremonia” (193).

El aspecto central de la feria es la glorificación del santo patrono San José, que tiene su origen, como la mayoría de las fiestas, en un hecho de extrañas características a las que se le atribuye origen sobrenatural, luego divino. Tal suceso crece al amparo de las creencias y necesidades espirituales de la gente del pueblo y patrocinado por la Iglesia Católica. El texto enfoca desde distintas perspectivas el fenómeno de la fiesta religiosa en honor a San José, considerando una diversidad de voces que representan la diversidad del pueblo y que incluye, en tono irrisorio, la voz del propio santo.

La feria se revela como un fenómeno complejo, de muchas aristas: la devoción religiosa, el ansia de libertad expresiva que entra en conflicto con las normas morales y sociales, los intereses personales y de clase, la intervención de la Iglesia y el Estado como organismos controladores y también interesados económicamente. Con todo, la feria es la gran instancia de encuentro colectivo en la que los sujetos despliegan su ser corporal y espiritual y se sienten ligados a un conjunto, a un pueblo. En la feria de Zapotlán, al igual que en la feria discursiva de la novela, converge la heterogeneidad latinoamericana.

\section{LO APOCALIPTICO DE LA CULTURA Y DE LA ESCRITURA}

En la parte central del texto, lo religioso cobra un carácter apocalíptico. Es el instante del temblor y la confesión colectiva. Estos fragmentos son una especie de síntesis estructural de la novela: en cada uno de ellos se aglutina una ráfaga de enunciados pertenecientes a distintos emisores, identificables o no, que representan al mar de voces que circulan por el texto. La separación de los enunciados de cada hablante en el fragmento del terremoto suele efectuarse por medio de los puntos suspensivos, que indican el corte y la supuesta continuidad del enunciado, pero la diferenciación de los discursos no es del todo clara en algunos casos. En el fragmento del terremoto una voz narradora se intercala entre las voces de los personajes para describir la escena de destrucción, lo que junto a los enunciados suplicantes y llenos de temor y desesperación de los personajes conforma un discurso que materializa la idea de tumulto, barullo y atropello físico. Se crea una atmósfera apocalíptica por el temor de los personajes, las apelaciones a Dios, la referencia a los efectos destructivos inmediatos del sismo y el discurso de ametralladora. Al final del fragmento los discursos sufren algunas mutaciones que los vuelven incoherentes y que se justifican por el momento álgido del temblor. Este es el instante en que se 
juntan todas las voces en un fragmento, porque todos están movidos por un mismo factor: el miedo a la muerte. El fin es salvar la vida o, en última instancia, el alma. México, al igual que muchos otros países hispanoamericanos, es un país terremoteado; como Chile, "ya no puede estar seguro de sus mapas", diría Fernando Alegría. Cualquier mañana puede ser apocalíptica y nos encuentra 'con el credo en la boca'.

En el fragmento del terremoto y sobre todo en el de la confesión se incorporan citas bíblicas que las emite una voz anónima, las que son adjudicables a don Isaías, pero también a la conciencia e inconsciente colectivos. Estas citas de los profetas bíblicos imprimen un tono que favorece a la atmósfera apocalíptica. Se trata de acusaciones del pecado, lamentaciones, advertencias y alusiones a hechos de destrucción y muerte. En el fragmento de la confesión aumentan los pasajes bíblicos, con lo que se agudiza el clima de culpa y castigo. La voz inicial se transforma en otras voces. La serie de confesiones las cierra un pasaje bíblico que recoge los pecados vertidos a lo largo del fragmento: "Perjuran, mienten, matan, roban, adulteran, oprimen y las sangres se suceden a las sangres" (93).

Los fragmentos cercanos a los del terremoto y la confesión tocan temas que se relacionan con el pecado. En unos la referencia es el juicio final, en otros se cita textualmente el Apocalipsis, en otros se imita el discurso del Apocalipsis mezclándose con situaciones de Zapotlán.

En el fragmento que sigue al de la confesión se insiste en lo apocalíptico al confrontar dos párrafos en paralelismo, uno es un pasaje del Apocalipsis y el otro una suerte de versión popular de éste. Ambos párrafos poseen la misma estructura y se refieren a la destrucción de la ciudad por el pecado. La voz de un narrador en tercera persona precede cada cita, la presenta:

Uno de por allí: "A nosotros se nos quedó la fama, pero los meros meros están aquí. Por eso Dios los castiga tanto. Síganle dando, síganle dando... más de veinte terremotos en lo que va de historia, y acuérdense, en 1912 el Volcán de Fuego por poco los tapa de azufre y ceniza ..."

Y otro ángel le siguió diciendo: "Ha caído Babilonia, aquella grande ciudad, porque ella ha dado a beber a todas las naciones del vino del furor de su fornicación...” (94).

Aquí se produce un diálogo entre el discurso religioso bíblico y el discurso religioso popular. La forma como el texto pone en diálogo a ambos muestra el modo irreverente con que la obra se relaciona con los discursos canónicos. No obstante, la popularización del discurso religioso no lo desacraliza en el caso particular de La feria, pues en otros momentos, como en algunos a los que ya me he referido, el discurso bíblico funciona en tono serio, lo que demuestra 
una flexibilidad en el tratamiento de los discursos que se expresa en la variedad tonal de la narración. De esta manera, ambos discursos se acercan, se contagian a través de una estructura lúdica. El autor acerca el discurso a la humanidad de su escritura y a la de los hablantes en general, de modo de hacer patente las relaciones dialógicas que habitan el lenguaje.

El discurso de don Isaías es eminentemente apocalíptico: advierte a los habitantes, a quienes considera hombres "malhechores", las consecuencias de sus actos, es decir, el castigo de Dios que se verifica en las catástrofes naturales o bien en el día del juicio que se anuncia a través de esas catástrofes. Este discurso quiere remecer la conciencia de los pecadores por medio del amedrentamiento.

Algunos fragmentos tocan el tema de la prostitución, otros tratan sobre los homosexuales. Estos dos últimos temas con sus respectivos discursos enmarcan significativamente los fragmentos del terremoto y la confesión, pues en la doctrina católica se considera a la prostitución y a la homosexualidad las causas de la destrucción de Sodoma y Gomorra y por ende se las asocia con el juicio y castigo divinos.

El segundo fragmento después del terremoto describe brevemente la atmósfera del pueblo y dice que un grupo de vecinos sacó en andas a San José. El fragmento siguiente enlaza con la procesión, pero desde la perspectiva del mismísimo santo, lo que produce un efecto de animación de la imagen que va en las andas. Se crea la idea de que hablara su conciencia a medida que lo pasean por el pueblo. La descripción que hace San José del estado de las cosas es coherente con la atmósfera producida por el temblor: "Y yo, José, me eché andar pero casi no avanzaba entre aquel mar de gente (...) me pareció ver como si el aire estuviera estremecido de asombro (...) Y al pasar por un aguaje vi unos bueyes que ponían en el agua sus hocicos pero no bebían. En una palabra, todas las cosas fueron apartadas de su curso normal" (88-89). Otra voz cierra el fragmento refiriéndose a la procesión y a San José, de quien dice que "se veía pálido y desencajado", lo que refuerza la idea de que habla su conciencia anteriormente. El pasaje tiene cierto parecido con las visiones de los profetas, porque es una descripción en primera persona que escapa a la realidad inmediata y cuyo significado es hermético, se resalta el acto de ver y mirar y, como en el Apocalipsis, el emisor se autonomina (yo, José).

De esta manera, el texto construye la asociación entre el terremoto y el castigo divino, pues el fenómeno telúrico adquiere connotaciones de destrucción apocalíptica. Si bien los lugareños están conscientes de que viven en un territorio vapuleado, sobre el que se cierne una destrucción impredecible, viven en contradicción con sus propias conciencias, a las que se enfrentan en una situación límite clamando “jJesucristo, aplaca tu ira y tu rigor!” Asociar los 
terremotos u otras catástrofes naturales con un signo de castigo divino, de juicio final, forma parte del imaginario judeocristiano de gran raigambre en Latinoamérica. Y es sin duda el Infierno y no el Paraíso el espacio en el que la religión más ha insistido a lo largo de nuestra historia.

Así como la novela es una feria de discursos, también es una escritura sísmica y apocalíptica, pues remece la estructura textual, la desbarata para que el lector hurgue en los escombros y esté despierto.

\section{EL DESTINATARIO SUPERIOR}

Para Bakhtin, en todo discurso está contenido un destinatario superior que es el tercero del diálogo, un receptor que es capaz de comprender el mensaje aun cuando el destinatario concreto no lo consiga o no le interese [Bakhtin 1989: 318-319]. Esta presencia abstracta corresponde en La feria a Dios, tanto en los discursos de los distintos emisores particulares como en la novela como discurso total.

En el discurso de Juan Tepano la presencia de Dios como interlocutor superior se manifiesta en ciertas expresiones que indican un diálogo interno. Así, por ejemplo, en el uso de la expresión "Sea por Dios" con el fin de dar mayor credibilidad a su discurso en relación con la versión que los culpabiliza: "Dizque lo matamos. Dicen que aquí, dicen que allá (...) Mentiras. Lo mataron en Cíbola a flechazos. Sea por Dios" (7). Con este enunciado apela a la creencia en un ser superior ubicuo, omnisciente y sagrado en cuyo nombre sólo se ha de decir la verdad. La expresión es equivalente al juramento: 'juro por Dios que digo la verdad' o 'Dios es testigo de que digo la verdad'. La fe en Dios y San José convierte a estos seres superiores en destinatarios que explícita o implícitamente comprenden el lenguaje del que los emite y los motivos y sentimientos que los mueve.

Este tercero superior es el factor común en el discurso de los emisores del texto y de los hablantes de Zapotlán, así como la feria es el acontecimiento que congrega a todos. Esta entidad inasible atraviesa clases y oficios. El cura del pueblo sube al cerro para tener una conversación con Dios, en donde le confía sus esfuerzos y sus frustraciones en la predicación del evangelio al pueblo de Zapotlán. Don Fidencio, el Presidente Municipal, reniega de San José, sin embargo no deja de creer en él, lo que se expresa en forma irrisoria: "Esto no quiere decir, señoras y señores, que yo, como presidente municipal, no esté dispuesto a colaborar con ustedes para que esta feria sea la mejor que ha habido en el pueblo, con permiso de José..." (75). Las constantes expresiones que apelan a Dios y que se usan en forma natural en el habla cotidiana se multipli- 
can e intensifican, tornándose ruegos desesperados en uno de los fragmentos climáticos del discurso que es el del terremoto: “¡Está temblando! Santo Dios, Santo Fuerte, Santo Inmortal... ¡Jesucristo aplaca tu ira, tu justicia y tu rigor!” (84-85).

Así como los discursos de los personajes poseen un destinatario superior, la novela como discurso unitario también y coincide con el anterior, es decir, es una voz que corresponde a la voz de Dios, sabedor y evaluador del discurso del autor. Esta presencia se manifiesta en uno de los fragmentos finales mediante una inversión formal de los factores comunicativos: "Y tú vete a dormir, contador impuntual y fraudulento. Pero como tu castillo de mentiras sostiene una sola verdad, yo te consiento, absuelvo y perdono. Y como creíste te sea hecho" (197). Esta voz evoca la voz de Dios, porque se yergue como superior por su tono imperativo y su facultad perdonadora y omnipotentte. ¿A quién apostrofa?: al narrador y también al autor en cuanto creador del texto (Poot-Herrera dice que correspondería al metanarrador, instancia intermedia entre el autor y el texto producido). La voz superior acusa al contador de "impuntual y fraudulento" y lo manda a dormir como a los niños que se han portado mal. Esta imagen minimizante tiene su compensación en la aprobación, no obstante, de la novela por parte de la voz divina que es la conciencia del mismo autor. La obra del escritor es para la voz superior mentira y verdad, ficción y realidad. Es coherente la interpretación de Poot-Herrera [1992: 196] al referirse a que lo que redimiría el "castillo de mentiras" (construcción ficticia) y daría valor al texto, desde la perspectiva de esta voz, sería "una sola verdad" que en el contexto de la novela es el abuso de poder y la injusticia, que han relegado al lugar más bajo a los indígenas.

Los dos versículos bíblicos del epígrafe, tomados de Isaías 49: 2, 8, establecen relación con el fragmento referido anteriormente. Estas citas representan un diálogo con el texto bíblico, crean un nuevo diálogo entre sí al confrontarse y establecen relaciones con la novela como globalidad y con fragmentos y discursos particulares dentro de ella. En la recontextualización, el diálogo entre Dios e Isaías puede ser entendido como un diálogo entre Dios y el autor.

El hizo mi lengua como cortante espada; él me guarda a la sombra de su mano, hizo de mí aguda saeta y me guardó en su aljaba.

Yo te formé y te puse por alianza de mi pueblo para restablecer la tierra y repartir las heredades devastadas.

Se destaca el lenguaje ("lengua"), que puede asociarse con la escritura. Es el lenguaje un instrumento, un arma activa y peligrosa. La metáfora compara al sujeto con la saeta, que da en un blanco y que hiere, pero cuyo movimiento 
depende de una mano superior. En el segundo versículo se especifica la función del sujeto y su palabra como un designio, lo que se conecta con el tema de la tierra y la situación de los indígenas: el sujeto aludido debe contar una historia, la historia de las tierras devastadas. Este sujeto puede ser entendido como el propio autor en su función escritural, destacándose la denuncia social; también puede asociarse con Juan Tepano, quien como Primera Vara de la Comunidad Indígena es el portavoz de la "alianza" por recuperar las tierras arrancadas. De esta manera, el tercero superior de la novela se manifiesta ya como emisor ("Yo te formé..."), ya como destinatario ("El hizo mi lengua"). La mirada de esta presencia superior creadora comprende, consiente y exhorta al autor-contador de la historia, poniendo énfasis en la función de decir o escribir.

El carácter esencialmente heterogéneo de la novela hace posible la convivencia de una dimensión realista, material, y otra religiosa, espiritual, trascendente, las que armonizan por medio del verosímil estético al que Arreola los somete. La escritura de Arreola es oscilante: el ludismo no se eterniza en el puro juego ni la realidad se petrifica en la denuncia social ni la presencia de Dios inhibe su espíritu cuestionador. El escritor reconoce lo gravitante del aspecto religioso en su vida, lo que también se hace presente en su escritura, como se aprecia en La feria: "Yo tuve una educación profundamente católica, entonces nunca podrán apartarse de mí las imágenes que corresponden al infierno dantesco y al infierno del catecismo ilustrado (...) yo sí vivo en un orbe de pensamiento religioso; sí, aunque sea un católico en bancarrota" (en Cárdenas 1994: 5). La obra de Arreola conserva un fondo de espiritualidad religiosa que deviene en algunos momentos en conciencia moral. Arreola establece un punto de encuentro entre él como escritor y sus lectores, el cual trasciende la experimentación formal y el ludismo. Con expresión bíblica, dice: "Me doy cuenta de que son lectores de veras, que no leen para que les cuenten historias, sino para que algo del misterio les sea revelado. Porque ésa es la función del escritor real".

\section{OBRAS CITADAS}

Alvarez, Gerardo.1996. Textos y discursos. Introducción a la lingüistica del texto. Concepción: Universidad de Concepción.

Juan José Arreola. 1963. La feria. México: Joaquín Mortiz. 1968. Confabulario. México: F.C.E.

Bakhtin, Mikhail. 1971. Rabelais. Barcelona: Bassal. . 1981. Problemas de la poética de Dostoievski. México: F.C.E. 1985. The dialogic imagination. Austin: University of Texas. 1989. Estética de la creación verbal. México: Siglo XXI. 
Cárdenas, María Teresa. 1994. “Juan José Arreola: 'Me he divertido mucho escribiendo"'. El Mercurio, Santiago, 3 de abril.

Coseriu, Eugenio.1962. Teoría del lenguaje y lingüistica general. Madrid: Gredos.

Dijk, Teun van. 1984. Texto y contexto. Madrid: Cátedra.

Menton, Seymour.1963. Juan José Arreola. La Habana: Cuadernos de la Casa de las Américas.

Mora Valcárcel, Carmen. 1990. "La feria o 'una apocalipsis de bolsillo". Revista Iberoamericana 150, enero-marzo: 204-230.

Ostria González, Mauricio. 1970. "El valor estructural del fragmento en La feria de Juan José Arreola". Estudios Filológicos 6: 180-210.

. 1998-99. "Función de la intertextualidad en la obra de Juan José Arreola”. Boletín de filología XXXVII: 887-897.

Paz, Octavio. 1990. El laberinto de la soledad. Buenos Aires: F.C. E.

This paper is a reading of La feria, a Juan José Arreola's novel, as an eminently dialogic, heterogeneous, carnavalesque and fragmentary text that constructs meanings at the macrostructure's level.

The treatment of the themes involves the formal writing structure. For this reason it's such an interesting novel. The "feria" as a religious and pagan holiday is the principal subject of this novel; but the text is a fair too, a discursive fair that includes diverse material and spiritual spheres. 